\title{
UNDERSTANDING PATENTS AND HOW TO COMPLETION OF RIGHTS ON PATENT RIGHTS
}

\author{
Doni Winata \\ 165100085 \\ Faculty of Computer, 4487571-83 \\ doniwinata.student@umitra.ac.id
}

\begin{abstract}
Patent is an exclusive right granted by the state to the inventor for the results of his invention in the field of technology for a certain period of time carrying out his own invention or giving approval to other parties to carry out. , can be a product or process or a product or process improvement and development.

Patents are given for inventions that are new and contain incentive steps and can be applied in the industry. The invention is considered new if at the date of receipt of the invention it is not the same as the previously disclosed technology. The invention in the form of a new product or tool which has practical use value is caused by its shape, configuration, construction or component can obtain legal protection in the form of a simple patent.
\end{abstract}

Keywords: Definition of Patents and How to Settle Intellectual Property Rights Regarding Patent Rights 


\section{A. INTRODUCTION}

UNDERSTANDING PATENTS AND HOW TO COMPLETION OF RIGHTS ON PATENT RIGHTS

\section{UNDERSTANDING PATENTS}

Patent is a special right given by the State to the inventor of his invention in the field of technology, for a certain period of time he himself implements his invention or gives his consent to others to implement it (Article 1 Paragraph 1 of the Law on Patents). The definition of another patent is an exclusive right granted by the state to the inventor for the results of his invention in the field of technology for a certain period of time carrying out his own invention or giving approval to other parties to carry out. technology, can be a product or process or a product or process improvement and development. Patents are given for inventions that are new and contain incentive steps and can be applied in the industry. The invention is considered new if at the date of receipt of the invention it is not the same as the previously disclosed technology. The invention in the form of a new product or tool which has practical use value is caused by its shape, configuration, construction or component can obtain legal protection in the form of a simple patent.

Based on Article 8 of Law Number 14 of 2001 concerning Patents, patents are granted for a period of 20 years, from the date of receipt and the term cannot be extended. Whereas for simple patents given a period of 10 years, starting from the date of receipt and the period cannot be extended. Patents are granted based on the application and each application can only be submitted for one invention or several inventions which constitute a unity of invention. Thus, the patent application is submitted by paying fees to the Directorate General of Patent Rights of the Ministry of Justice and Human Rights. However, applications can be changed from patents to simple patents. Based on Article 66 of Law Number 14 of 2001 concerning Patents, patents can be transferred either in part or in part due to 
inheritance, grants, wills, written agreements and other reasons justified by legislation by recording by the directorate general of patent transfer. Examples of patents: how to obtain patent rights in Indonesia, namely adhering to the principle of first-tofile, which means that anyone registering his invention for the first time in the Patent office will get a patent. Examples of patents: how to obtain a patent in the United States, namely adopting sisteem first-toinvent, where patents are given to someone who first discovered. Special rights granted by the state to the inventor for the results of his discoveries in the field of technology, for a certain period of time implementing the invention itself or giving approval to others to implement it (Article 1 of the Patent Law). Patents are given within the scope of the technology field, namely science that is applied in industrial processes. In addition to patents, also known as simple patents (utility models) that are almost the same as patents, but have simpler protection conditions. Simple patents and patents in Indonesia are regulated in the Patent Law (UUP). Patents are only given by the state to inventors who have found a new invention in the field of technology.

\section{How to Resolve Haki Regarding}

\section{Patent Rights}

Laws Governing Patent Rights

1. Law No.14 of 2001 concerning Patents (UUP);

2. Law No.7 of 1994 concerning Agreement Establishing the Word Trade Organization (Approval of Establishment of a World Trade Organization);

3. Decision No. 16 of 1997 concerning Ratification of the Paris Convention for the protection of Industrial Property;

4. Government Regulation No. 34 of 1991 concerning Procedures for Government Patents;

5. Government Regulation No. 11 of 1991 concerning the Form and Content of Patent Letters;

6. Minister of Justice Decree No. 1991 M.01-HC.02.10 concerning Simple Patents; 
7. Minister of Justice Decree No. M.02-HC.01.10 of 1991 concerning the implementation of patent announcements;

8. Minister of Justice Decree No. 1991 N.04-HC.02.10 concerning Requirements, Term and Procedure for Payment of Patent Fees;

9. Minister of Defense Decree No.M.06.- $\quad$ HC.02.10 of 1991 concerning Implementation of Submission of Patent Requests;

10. Minister of Justice Decree No. 1991 M.07-HC.02.10 concerning Forms and Requirements for Substantive Patent Examination;

11. Minister of Justice Decree No. M.08-1991 HC.02.10 concerning Recording and Requesting Copies of Patent Documents;

12. Minister of Justice Decree No. M.04-PR.07.10 of 1996 concerning the Patent Appeal Commission Secretariat;

13. Minister of Justice Decree No. 1991 M.01-HC.02.10 concerning Procedures for Submitting Patent Appeal Requests.
Legal Basis of PATENT RIGHTS:

1. Law Number 6 Year 1989 concerning Patents (Republic of Indonesia State Gazette Year 1989 Number 39)

2. Law Number 13 of 1997 concerning Amendment to Law Number 6 Year 1989 concerning Patents (Republic of Indonesia State Gazette Year 1997 Number 30)

3. Law Number 14 Year 2001 concerning Patents (Republic of Indonesia State Gazette Year 2001 Number 109)

Patent dispute resolution through the Commercial Court is regulated in Article 117 of the Law - a patent in which the party entitled or subject to patent (regulated in Article 10, Article 11, and Article 12) can sue the commercial court if a patent is granted to another party aside from those who are entitled.

As a Commercial Judge examining patent disputes must understand the case and its protection criteria, namely: 1. Is included a protected object. 
2. Is included criteria excluded from protection.

3. Does it meet the protected requirements.

4. Is registered in the destination country where protection is expected.

5. While the causes of disputes in patent rights disputes are usually:

1) Unclear ownership status.

2) Use of patents without permission of the owner.

3) Not fulfilled the patent license agreement.

By means of the Commercial Court which is considered to understand the criteria for patent disputes, justice is expected to be truly achieved and satisfying. Ideally each Judge's decision contains 3 (three) elements, namely:

1. Elements of legal certainty.

2. Elements of expediency.

3. Elements of justice.

\section{B. CONCLUSION}

Based on the discussion from the previous chapter conclusions can be taken as follows:

Definition of Patent Rights or definition of patent rights is an exclusive right granted by the state to inventors for the results of their invention in the field of technology, which for a certain period of time carries out its own invention or gives its approval to other parties to implement it.

Definition of Patent Rights or the definition of patent is a form of protection of intellectual property rights that is very effective because it can prevent the implementation of inventions by other parties without permission from the holder of the patent, even though the other party obtains the technology independently (not imitating). According to patent law No. 14 of 2001 (2001 patent law), patents granted for inventions that meet the requirements of novelty, contain inventive steps \& can be applied in industry for 20 years.

By means of the Commercial Court which is considered to understand the 
criteria for patent disputes, justice is expected to be truly achieved and satisfying. Ideally each Judge's decision contains 3 (three) elements, namely:

1. Elements of legal certainty.

2. Elements of expediency.

3. Elements of justice.

C. ACKNOWLEDGEMENT

University Of Mitra Indonesia

\section{REFERENCE(Based ISO 690 )}

A. S. Putra And O. M. Febriani, "Knowledge Management Online Application In Pdam Lampung Province," In Prosiding International Conference On Information Technology And Business (Icitb), 2018, Pp. 181-187.

[2] A. S. Putra, O. M. Febriani, And B. Bachry, "Implementasi Genetic Fuzzy System Untuk Mengidentifikasi Hasil Curian Kendaraan Bermotor Di Polda
Lampung," J. Sist. Inf. Dan Manaj. Basis Data, Vol. 1, No. 1, Pp. 21-30, 2018.

[3] O. M. Febriani And A. S. Putra, "Sistem Informasi Monitoring Inventori Barang Pada Balai Riset Standardisasi Industri Bandar Lampung," J. Inform., Vol. 13, No. 1, Pp. 90-98, 2014.

[4] Putra, Arie Setya. "2018 Artikel Struktur Data, Audit Dan Jaringan Komputer." (2018).

[5] Putra, A. S. (2018, July 17). Paperplain Fundamental Create Application With Borland Delphi 7.0 University Of Mitra Indonesia. Retrieved From Osf.Io/Pbrn9.

\section{E. REFERENCE(Based APA )}

Putra, A. S., Aryanti, D. R., \& Hartati, I. (2018, November). Metode SAW (Simple Additive Weighting) sebagai Sistem Pendukung Keputusan Guru Berprestasi (Studi Kasus: SMK Global Surya). In Prosiding Seminar Nasional Darmajaya (Vol. 1, No. 1, pp. 85-97). 
Sari, D. P., Febriani, O. M., \& Putra, A. S. (2018, November). Perancangan Sistem Informasi SDM Berprestasi pada SD Global Surya. In Prosiding Seminar Nasional Darmajaya (Vol. 1, No. 1, pp. 289-294).

Putra, A. S. (2018). Paperplain: Execution Fundamental Create Application With Borland Delphi 7.0 University Of Mitra Indonesia.

Putra, A. S., Sukri, H., \& Zuhri, K. Sistem Monitoring Realtime Jaringan Irigasi Desa (JIDES) Dengan Konsep Jaringan Sensor Nirkabel. IJEIS (Indonesian Journal of Electronics and Instrumentation Systems), 8(2), 221232.

Darmawan, A., Yuliawati, D., Marcella, O., \& Firmandala, R. (2016). Sistem Absensi dan Pelaporan Berbasis Fingerprint dan SMS Gateway. EXPLORE, 7(1).

Febriani, O. M., Wahyuni, T., \& Yusuf, S. (2017). DESIGN OF WEBSITE-BASED INFORMATION SYSTEM FOR EDOCUMENT
ADMINISTRASI IN THE COMMUNITY SERVICE UNIT (A Case Study at Rajabasa District). INTERNATIONAL JOURNAL OF COMPUTERS \& TECHNOLOGY, 16(7), 7010-7020.

Febriani, O. M., \& Wahyuni, T. (2017, October). PERANCANGAN SISTEM E-DOCUMENT ADMINISTRASI LOGBOOK PENELITIAN PADA UNIT LAYANAN DI BANDAR LAMPUNG. In Prosiding Seminar Nasional Darmajaya (Vol. 1, No. 1, pp. 187-194).

Febriani, O. M., \& Permadi, A. B. (2017). Implementasi Sistem Aplikasi Data Bimbingan dan Pelanggaran Siswa pada Sekolah Menengah Atas di Lampung Tengah dengan Metode Analisis dan Desain Sistem Terdistribusi (SSAD). EXPERT, 7(1).

Febriani, O. M., \& Ambarwati, L. (2015). PERANCANGAN APLIKASI PENGOLAHAN DATA PENJUALAN UKM KELANTING KHAS TELO DESA SIDOHARJO KECAMATAN JATI AGUNG 
Fakultas Komputer

Doni Winata

Section Class Content

KABUPATEN

LAMPUNG

SELATAN. Jurnal Teknologi

Informasi dan Bisnis Pengabdian

Masyarakat Darmajaya, 1(1), 77-95.

Febriani, O. M. (2015). Rancang

Bangun Aplikasi E-

commercemenggunakan Freewebstore

pada UKM Kelanting di Desa

Sidoharjo Lampung Selatan. Prosiding

Sembistek 2014, 1(02), 446-458. 